\title{
PYCNOGONIDA OF SAGAMI BAY
}

\author{
$\operatorname{AUTHOR}(S):$
}

Utinomi, Huzio

CITATION:

Utinomi, Huzio. PYCNOGONIDA OF SAGAMI BAY. PUBLICATIONS OF THE SETO MARINE BIOLOGICAL LABORATORY 1959, 7(2): 197-222

ISSUE DATE:

1959-05-30

URL:

http://hdl.handle.net/2433/174610

RIGHT: 


\title{
PYCNOGONIDA OF SAGAMI BAY ${ }^{1)}$
}

\author{
Huzio UTINOMI
}

Seto Marine Biological Laboratory, Sirahama

With 9 Text-figures

The present paper deals with the Pycnogonida from the collections in the Biological Laboratory of His Majesty the Emperor in Tokyo which have been assembled from Sagami Bay during the period from 1928 to 1958.

Although the pycnogonid collection is not extensive, only comprising 43 vials, it was revealed to represent 18 species belonging to 11 genera in all. Most of them are endemic to or common in Japanese waters, but a few which have been known only from southern tropical waters are added for the first time to the Japanese fauna. Moreover, the present collection revealed some remarkable examples, interesting from a taxonomic point of view, necessitating an emendation of some generic or specific characters in some genera of the Ammotheidae.

The pycnogonid fauna in Sagami Bay and the neighboring waters is locally better known than in other areas of Japan, thanks to the works by Japanese authors (FukUI, Kishida, OhShima and Utinomi) and several foreign authors (Böhm, Slater, Hoek, Ives, Ortmann, Loman, Helfer, HedGreth and Stock). Earlier records of pycnogonids from this district by these investigators are given at the end of this paper in order to summarize our present knowledge of the pycnogonid fauna of Sagami Bay.

I am greatly indebted to Dr. Hirotaro HATTORI of the Biological Laboratory of His Majesty the Emperor and staff members for the privilege of studying this interesting collection.

In the following list the species marked with an asterisk (*) are now newly added to the Japanese fauna.

Family Nymphonidae

Nymphon grossipes (O. FABRICIUS?) KRøYER

Nymphon japonicum ORTMANN

Family Callipallenidae

Propallene longipes (BöHM)

Pallenopsis sibogae Loman

1) Contributions from the Seto Marine Biological Laboratory, No. 323.

Publ. Seto Mar. Biol. Lab., VII (2), 1959. (Article 9) 
Pallenopsis virgata LOMAN

Family Phoxichilidiidae

*Anoplodactylus versluysi LOMAN

Family Ammotheidae

Achelia echinata HODGE

Achelia superba LOMAN

*Ammothella indica STock

Nymphopsis muscosa LoMAN

Cilunculus armatus (BОНM)

Ascorhynchus japonicum Ives

Ascorhynchus auchenicum (SLATER)

Ascorhynchus ramipes (BöHM)

Ascorhynchus glaberrimum SCHIMKEWITSCH

Lecythorhynchus hilgendorfi (BӧHM)

*Lecythorhynchus hedgpethi $\mathrm{n}$. sp.

Family Pycnogonidae

Pycnogonum tenue KIsHida

\section{Description of the Species}

\section{Family Nymphonidae}

\section{Genus Nymphon J. C. FABRICIUS, 1794}

\section{Nymphon grossipes (O. FABRICIUS ?) KR $\not \mathrm{YER}$}

Nymphon grossipes HedgretH, 1948, p. 187, fig. 13a; HedGPeth, 1949, p. 247 (synonymy); UTINOMI, 1955, p. 4, fig. 1; STOCK, 1955, p. 218.

Material: 1 male (Sp. No. Pycn. 6). $100 \mathrm{~m}$ east of Okinose Bank ${ }^{13}$. Depth unrecorded. 4-VIII-1936.

1 female (Sp. No. Pycn. 38). Mosaki, Kamegisyô, 8 fathoms. 24-VIII-1957.

Remarks: This circumpolar, boreal-arctic species was already collected off Simoda by the 'Sôyô-maru' (UTINOMI, 1955).

Measurements of a male and a female in $\mathrm{mm}$ :

$\begin{array}{lcc} & \text { Male (no. 6) } & \text { Female (no. 38) } \\ \text { Length of proboscis } & 3.0 & 2.5 \\ \text { Diameter of proboscis } & - & 0.7 \\ \text { Length of trunk } & 6.0 & 2.5 \\ \text { Width of trunk (excl. crurigers) } & - & 0.5 \\ \text { Length of crurigers } & - & 0.3 \\ \text { Length of abdomen } & 1.0 & 0.2 \\ \text { Space between crurigers } & - & 0.3\end{array}$

1) Localities in the succeeding text are all included in Sagami Bay. 


\section{Nymphon japonicum ORTMANN}

Nymphon japonicum Ortmann, 1890, p. 158, pl. 24, fig. 1 (part); Hedgreth, 1949, p. 249, fig. 20 ; UтіNomI, 1951, p. 159 ; Sтоск, 1954, p. 18, fig. 6a-e ; UтіNomi, 1955, p. 5.

Material: 7 males (Sp. No. Pycn. 17). Maruyama-dasi, Amadaiba, 218 m. 19VII-1952.

1 male (Sp. No. Pycn. 26). West of Aoyama-dasi, Amadaiba, 110 m. 15-III-1956.

Remarks: This is prevalent and apparently endemic in Japanese waters.

\section{Family Callipallenidae \\ Genus Propallene Schimkewitsch, 1909 \\ 3. Propallene longiceps (ВӧнM)}

Pallene longiceps Böhm, 1879b, p. 59 ; OrTMAnN, 1890, p. 165, pl. 24, fig. 7 ; Fukur, 1918, p. 99 ; Ohshima, 1933a, p. 96 ; Ohshima, 1933c, p. 212, figs. 1-7.

Propallene longiceps Scurmkewitsch, 1930, p. 282 (1929, fig. 3); OHshima, 1936, p. 863 (listed only); Sтоск, 1954, p. 31, fig. 12a-b.

Material: 1 male and 1 female (Sp. No. Pycn. 23). Off Simoda, 20 m. ?-XI-1954.

Remarks: In a male specimen, a pair of rudimentary 2-jointed palps are present on the ventral side at the base of chelifores, as figured by Schimkewitsch and OHSHima. It is rather robust and shorter than that of the allied $P$. kempi. (CALMAN), as noticed by STock (1954). In a female specimen, the femur of all legs is plump, fusiform, containing 2 or 3 orange-colored eggs.

This species seems to be endemic to Japanese waters at present, and has often been recorded. The present material, brownish in color, is apparently benthic, but as exemplified by OHsнima $(1933 \mathrm{a}, \mathrm{c})$ this is often found in plankton. Indeed, I have found this species in plankton samples collected by Dr. I. YAMAZI during his plankton investigation in bays along the Japanese coasts ( 9 specimens from Kamaisi Bay of Tôhoku district on September 30,1952; 12 specimens from Tanabe Bay of Kii district in September, 1956).

\section{Genus Pallenopsis WILson, 1881}

\section{Pallenopsis sibogae LOMAN}

Pallenopsis sibogae Loman, 1911, p. 14 ; Sтоск, 1954, p. 63, fig. 30h-i (synonymy); Utinomi, 1955, p. 19, fig. 11.

Material: 1 female (Sp. No. Pycn. 7). South of Zyôgasima, 70 fathoms. 8-VIII1936.

1 female, damaged (Sp. No. Pycn. 18). Maruyama-dasi, Amadaiba, $80 \mathrm{~m} .21-\mathrm{VII}-$ 1952. 
Remarks: This is the third record of occurrence in Japan. Formerly STock (1954) recorded from the west of Kyusyu, $90 \mathrm{fms}$. and UTINOMI (1955) from Suruga Bay, $79 \mathrm{~m}$.

\section{Pallenopsis virgata LOMAN}

Pallenopsis virgatus Loman, 1908, p. 69, pl. 9, fig. 134 ; pl. 10, figs. 135-136; HedGPETH, 1949, p. 277, fig. $36 \mathrm{~g}-\mathrm{h}$; UTINOMI, 1951, p. 160.

Material: 1 male (Sp. No. Pycn. 13). Haikosine, 30-32 m. 8-VIII-1950.

Measurements of a male in $\mathrm{mm}$ :

$\begin{array}{lr}\text { Length of proboscis } & 2.5 \\ \text { Length of trunk } & 5.0 \\ \text { Length of abdomen } & 1.5 \\ \text { Length of crurigers } & 1.5 \\ \text { Length of 4th leg } & 25.0\end{array}$

Remarks: As in the preceding sibogae, there is a rounded tubercle below the basis of the chelifore as a vestige of palp. The presence of paired tubercles on the dorso-distal end of coxa 1 and a strong protuberance on the ventro-distal end of coxa 2 is characteristic to this species.

Hitherto records in Japanese waters are from the southwest of Omaé-zaki, 34-37 fathoms ('Albatross' Station 3730) and from off Yuzaki, Kii Peninsula, 25-35 m.

\section{Family Phoxichilidiidae \\ Genus Anoplodactylus WiLson, 1878 \\ 6. Anoplodactylus versluysi LOMAN}

Anoplodactylus versluysi Loman, 1908, p. 73, pl. 3, figs. 33-39; Sтоск, 1954, p. 48, figs. $38 \mathrm{a}, 39$.

Material: 1 female (Sp. No. Pycn. 28a). Aoyama-dasi, Amadaiba, 70-90 m. 15VI-1956.

1 young male (Sp. No. Pycn. 31). Kannonzuka-dasi, Amadaiba, 66-75 m. 14-II1957.

Remarks: Two specimens, both female and young male, largely coincide with the description of $A$. versluysi by Loman (1908) and STOCK (1954), although a few differences are found.

In a female specimen, the oviger is lacking, but its vestige is seen inserting between the bases of the first leg and the proboscis. Lateral processes are widely separated by twice their own diameter. On the ventral surface of the proboscis there is found a large, somewhat conical, mound instead of 4 papillae (such as figured by STOCK). The ocular tubercle is sharply pointed at tip and with 4 well-pigmented 
eyes rather downwards. Of the legs, coxa 1 is armed with a spiny tubercle at the dorso-distal end.

In a young male, the characteristic tubercle on the ventral surface of the proboscis is indistinct, as LOMAN neither mentioned nor figured. Probably such variation in the ventral outgrowth of the proboscis may be dependant on the sexual difference. The oviger is short and unsegmented. However, the presence of a peculiar tall ocular tubercle and a spiny tubercle on the distal end of coxa 1 indicates to be identical.

Measurements of a young female in $\mathrm{mm}$ :

$\begin{array}{ll}\text { Length of proboscis } & 1.0 \\ \text { Length of trunk } & 2.5 \\ \text { Length of abdomen } & 0.5\end{array}$

Family Ammotheidae

Genus Achelia HoDGE, 1864

\section{Achelia echinata HODGE}

(Fig. 1)

Achelia echinata UTINomI, 1954, p. 11, figs. 4-5 (synonymy).

Achelia echinata ssp. nasuta Sтоск, 1956, p. 98, fig. 16a (synonymy).

Material: 1 male and 2 ovigerous males (Sp. No. Pycn. $5 \mathrm{a}$ ). $30 \mathrm{~m}$ south of Enosima. Depth unrecorded, 27-II-1938.

1 male (Sp. No. Pycn. 16). Sabane, off Hayama. Depth unrecorded. 26-VII-1929.

1 male (Sp. No. Pycn. 21). Kasazima, shallow water. 22-VII-1952.

2 ovigerous males (Sp. No. Pycn. 35). Mosaki, Kamegisyô, 7-8 fathoms. 19-VII1957.

Remarks: All the material from Sagami Bay agree well with the specimens from Akkeshi Bay, Hokkaido (UTINomI, 1954, p. 11) and those from Tsingtao, North China which were described under the varietal name var. sinensis (LoU, 1936a, p. 19, figs. $7-9$, pls. II-IV).

In naming the specimen (a female) obtained off the Marine Biological Station, Misaki, 200 fathoms, STOCK (1956, p. 98) adopted a subspecific name nasuta MARCuS, 1940 (substitute for ssp. orientalis LosINA-LOSINSKY, 1933).

The typical form of Achelia echinata HODGE is widely distributed in the North Atlantic waters as far south as the Cape Verde Islands. Recently STOcK (1955) recorded it from St. Croix, West Indies. It was not known from the western side of the Atlantic before, yet he did not detect any reliable difference between the West Indian material and the European form.

With respect to the affinity of the oriental form, Lou (1936a) Iay too much stress on the relative length of the chelifore and abdomen to the trunk, as differentiating from the European form. STоск (1956) also emphasizes the slenderness of legs and 
the larger size in adults of the oriental form, relative to the European form.

In my opinion, however, such differences in size seem to be less reliable for exact discrimination of many individuals from different localities. Even if such differences are recognizable as constant, the proposal of nasuta by MARcus (1940) to cover the LosinA-Losinsky's homonymy is unnecessary, since Lou's var. name sinensis precedes Marcus' ssp. name nasuta.

As to another form Achelia echinata var. japonica, briefly described by ORTMANN (1890) from Kadsiyama (=Katuyama), mouth of Tokyo Bay, I already suggested that it is not identical with Achelia echinata.

According to OrTmann's figure (pl. 24, fig. 6), the proboscis is plump, nearly oval instead of being pointed distally, the chelifore relatively very short, the trunk as long as wide, well-segmented, without tubercles and the abdomen very short, almost
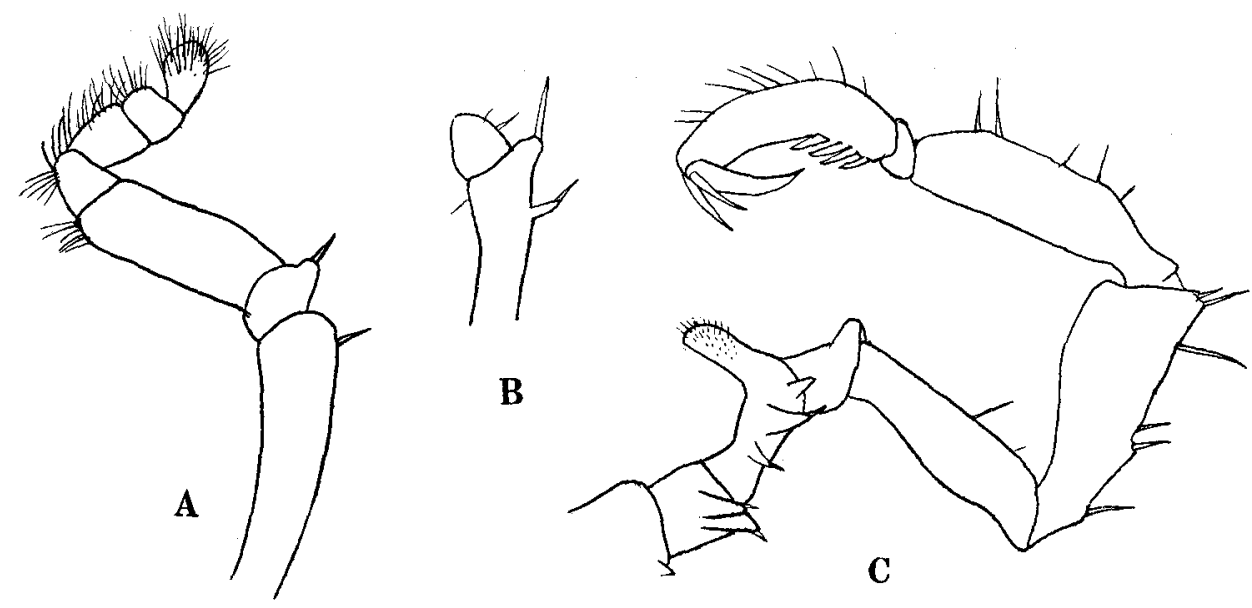

Fig. 1. Achelia echinata HoDGE.

A, palp; B, chelifore; C, fourth leg of male (Sp. No. 35).

(A-B 15, C $\times 35)$

hidden below. It may be, if distinct, allied to either $A$. bituberculata Hedgreth or $A$. ohshimai UTINOMI more closely than to other species. Rediscovery of new material will decide its status finally.

Achelia echinata seems to be essentially a boreal species ubiquitous in the northern hemisphere. Its range can be extended to the eastern Mediterranean (STock, 1958, p. 1) and to the Red Sea (CALMAN, 1938, p. 160).

\section{Achelia superba (LomAN)}

Ammothea superba Loman, 1911, p. 11, pl. 1, figs. 14-15 \& pl. 2, figs. 16-24 ; Funu, 1918, p. 98 (listed only); OHshrma, 1936, p. 866 (listed only).

Achelia superba Hedgpeth, 1949, p. 287; Utinomi, 1951, p. 160; Stock, 1954, p. 96 ; UtrNomi, 1955, p. 23, fig. 13. 
Material: 1 male (Sp. No. Pycn. 15). Kannonzuka-dasi, Amadaiba, 70 m. 13-XI1950.

1 ovigerous male (Sp. No. Pycn. 19). Maruyama-dasi, Amadaiba, $80 \mathrm{~m} .12-\mathrm{VII}-$ 1952.

1 male (Sp. No. Pycn. 28b). Aoyama-dasi, Amadaiba, 70-90 m. 15-VII-1956.

2 males (Sp. No. Pycn. 34). Aoyama-dasi, Amadaiba, 74-86 m.

1 male (Sp. No. Pycn. 42). Kannonzuka-dasi, Amadaiba, 65-72 m. 19-XII-1958.

8 ovigerous males (Sp. No. Pycn. 43). Between Kannonzuka-dasi and Aoyama-dasi, Amadaiba, 75-82 m. 19-XII-1958.

Remarks: This deep-water species unique for the genus has been frequently collected in Sagami Bay, ranging from $37 \mathrm{~m}$ to $180 \mathrm{~m}$ in depth.

\section{Genus Ammothella VerRILL, 1900}

\section{Ammothella indica $\mathrm{STOCK}$}

(Figs. $2 \& 3$ )

Ammothella indica Sтоск, 1954, p. 113, figs. 54-56c, 57a-c.

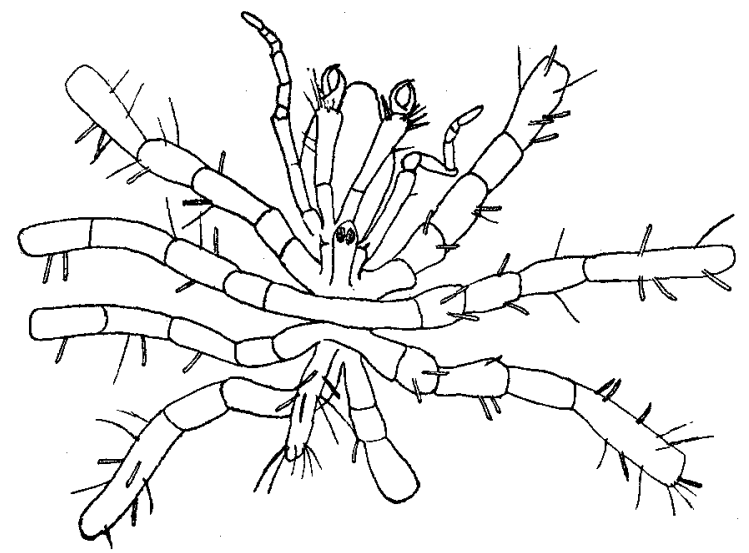

Fig. 2. Ammothella indica STock.

Immature specimen (Sp. No. 5), distal joints of legs omitted. $(\times 28)$

Material: 2 juveniles (Sp. No. Pycn. $5 \mathbf{b}$ ). $30 \mathrm{~m}$ south of Enosima. Depth unrecorded. 8-VIII-1936.

Remarks: Two immature specimens obtained in Sagami Bay, only $2.3 \mathrm{~mm}$ in total length from the tip of proboscis to the end of abdomen, agree well with Ammothella indica STock (1954) recorded only from Sunda Straits (30 $\mathrm{m}$ deep) and Singapore (at low tide). 
The trunk is distinctly segmented, with long lateral processes which are separated by about half their own diameter. The ocular tubercle is very elongated, constricted at base, with 4 well-pigmented eyes near the distal end; on each side of its base a spine-bearing protuberance (not mentioned by STOCK) is situated.

Abdomen is much long, curved upwards; in the middle and near the end there are brushes of simple and peculiar, somewhat shorter, hollow spines.

Proboscis is pyriform, widest in the middle and finely striated in rings. Chelifores, longer than proboscis, are also adorned with normal and hollow spines though loosely.

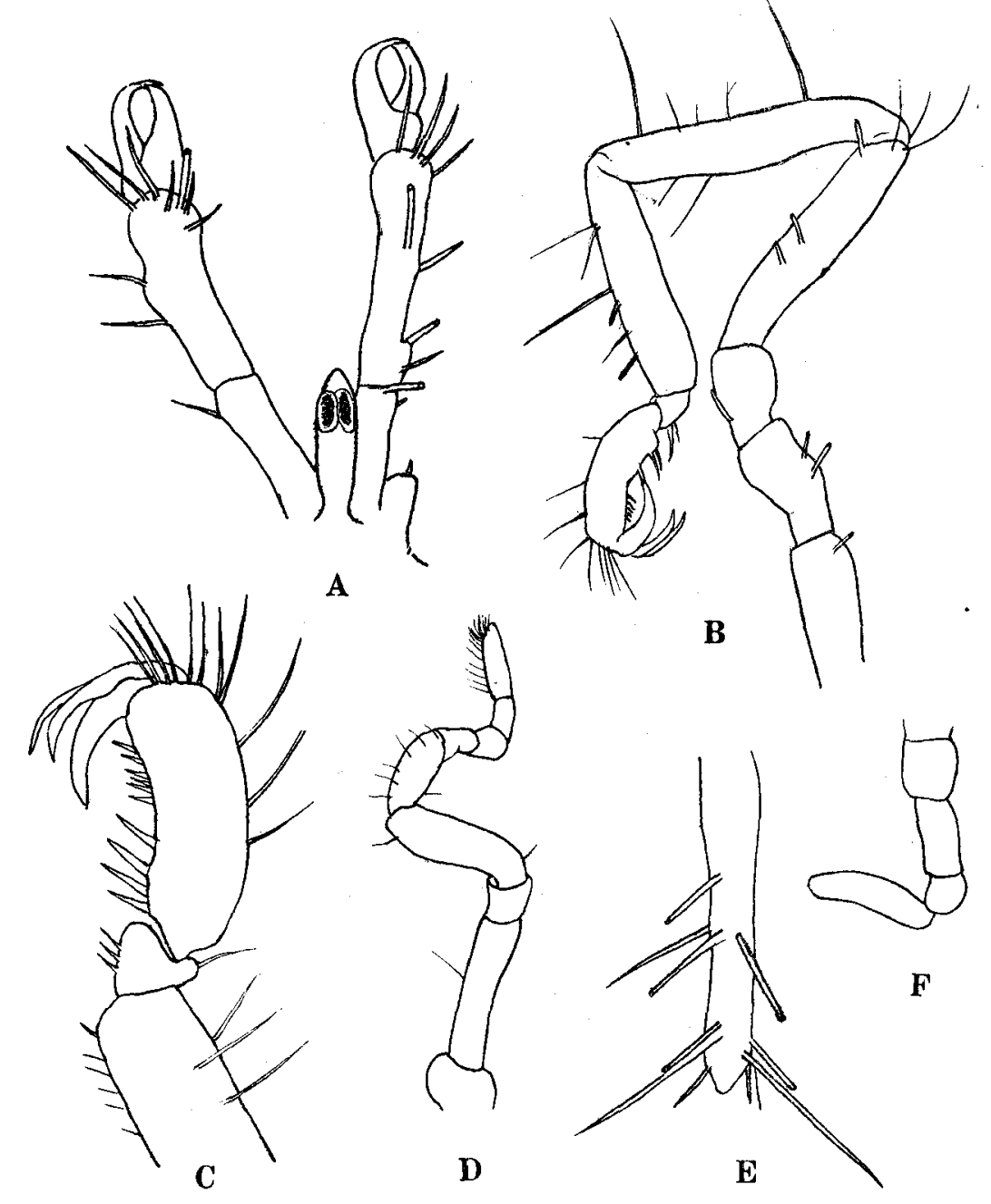

Fig. 3. Ammothella indica Sтоск.

A, ocular tubercle and chelifores; B, fourth leg; C, distal joints of fourth leg;

D, palp; E, abdomen; F, oviger still undeveloped.

$(\mathrm{F} \times 28, \mathrm{~B} \times 33, \mathrm{C} \times 67, \mathrm{~A}, \mathrm{D}, \mathrm{E} \times 207)$ 
The scape is 2-jointed, distal joint about twice as long as proximal one. The chela is still chelate, composed of strongly incurved fingers, gaping when closed.

Palpus 9-jointed, with normal spines and setae only. Oviger still undeveloped, 4-jointed only.

All legs are very slender and armed with hollow spines and normal spines rather sparsely. Propodus slender, slightly curved and with 2 or 3 basal spines and 6 or 7 smaller distal spines. Terminal claw is strong and auxilliaries slender, only a little shorter than the former.

\section{Genus Nymphopsis HASwELL, 1884}

\section{Nymphopsis muscosa LOMAN}

Nymphopsis muscosus Loman, 1908, p. 52, pl. 13, figs. 175-188; LoMAN, 1911, p. 11; FUKUI, 1918, p. 99 (listed only); OHshima, 1936, p. 864 (listed only).

Nymphopsis muscosa Sтоск, 1953, p. 307 ; Sтоск, 1954, p. 121.

Material: 1 male (Sp. No. Pycn. 10). $600 \mathrm{~m}$ west of Nisinosaki, Hatune, $17 \mathrm{~m}$. 29-VIII-1940.

1 ovigerous male (Sp. No. Pycn. 36). Mosaki, Kamegisyô, 7-8 fathoms. 16-VII1957.

Measurements of an ovigerous male in $\mathrm{mm}$ :

$\begin{array}{ll}\text { Length of chelifore } & 2.0 \\ \text { Length of trunk } & 2.0 \\ \text { Length of abdomen } & 1.5\end{array}$

\section{Genus Cilunculus Loman, 1908}

\section{Cilunculus armatus (Вӧнм)}

Cilunculus armatus Utinomi, 1955, p. 27, fig. 16 (synonymy).

Material: 1 female (Sp. No. Pycn. 39). Mosaki, Kamegisyô, 8 fathoms. 24-VII1957.

Measurements of a female in $\mathrm{mm}$ :

Length of chelifore $\quad 0.4$

Length of proboscis $\quad 2.5$

Length of trunk $\quad 3.0$

Length of abdomen $\quad 1.3$

Genus Ascorhynchus G. O. SARS, 1877

12. Ascorhynchus japonicum IvEs

Ascorhynchus japonicum STOck, p. 126, figs. 61-62; UtinOMI, 1955, p. 24 (synonymy). 
Material: 1 ovigerous male (Sp. No. Pycn.2). West of Amadaiba, 150 fathoms. 26-VII-1935.

1 male (Sp. No. Pycn. 3). South of Amadaiba, 150 fathoms. 8-IX-1935.

1 male (Sp. No. Pycn. 14). Nakabukari, off Nagai, $300 \mathrm{~m}$. 8-VIII-1950.

Measurements of a large male (no. 14) in $\mathrm{mm}$ :

Length of proboscis $\quad 15.0$

Length of trunk 20.0

Length of abdomen $\quad 6.5$

Length of chelifore 5.0

Length of fourth leg $\quad 85.0$

\section{Ascorhynchus auchenicum (SLATER)}

(Fig. 4A)

Parazetes auchenicus StATER, 1879, p. 281; HOEK, 1881, p. 26 (listed only).

Ascorhynchus bicornis ORTMANN, 1890, p. 162.

Ascorhynchus ramipes LOMAN, 1911, p. 9 (partim).

Ascorhynchus sp. (from Hôzyô, Prov. Awa) Fukui, 1918, p. 97 (figured only).

Ascorhynchus minutus Schimkewirsch, 1929, p. 111, figs. 26-27 (not HoEK).

Ascorhynchus auchenicus CAlman, 1922, p. 199, figs. 1-4 ; OHSHIMA, 1936, p. 864 (listed only); HEDGPETH, 1949, p. 291.

Ascorhynchus auchenicum Sтоск, 1954, p. 124, figs. 59-60 (synonymy).

Material: 1 male (Sp. No. Pycn. 4). Maruyama-dasi, Amadaiba, 80 fathoms. 16-VIII-1936.

1 male (Sp. No. Pycn. 29). Aoyama-dasi, Amadaiba, 70-90 m. 22-VII-1928.

1 ovigerous male (Sp. No. Pycn. 30). Off west of Nityôdani, Misaki, 91 m. 19-I1957.

Remarks: Recently STOCK (1954) discussed in detail on the dissimilarity between As. auchenicum and As. minutum HoEk known only from South Australia.

As. auchenicum appears therefore to be confined to Japanese waters at present. As STock suggests, As. minutus recorded by SchIMkEwitsch (1929) from Misaki is apparently an error for As, auchenicum.

In the present material, the median tubercles on the dorsum of the trunk are comparatively low, while the distal tubercle of the crurigers is tall and robust. In the legs, coxa 1 is provided with a pair of strong tubercles obliquely projecting at the distal end, and coxa 2 with a knob-like, low tubercle about midway on the dorsal surface.

In the posterior legs, the terminal claw is less than one-third as long as the propodus. In the anterior legs, however, it is much shorter. The abdomen reaches to the end of coxa 1 of the last legs. A pair of minute tubercles which are not so prominent as the paired frontal tubercles on the head are seen on the dorsal surface of the stalk of proboscis. 
Measurements of a male (no. 29) in $\mathrm{mm}$ :

Length of proboscis

Length of trunk $\quad 8.0$

Length of chelifore

1.5

Length of abdomen $\quad 1.9$

Width of trunk (excl. crurigers)

0.7

Length of crurigers 1.5

Space between crurigers

1.0

Diameter of crurigers

14. Ascorhynchus ramipes (BöHM), syn. nov.

(Fig. 4B)

Gnamptorhynchus ramipes ВӧHм, 1879b, p. 56, fig. 1.

Ascorhynchus ramipes HOEK, 1881, p. 25 (listed only); ORTMANN, 1890, p. 161, pl. 24, fig. 4 ; Loman, 1911, p. 6 (partim); Fuku, 1918, p. 98 (listed only); OHshima, 1936, p. 865 (listed only); HeDgPeTH, 1949, p. 292.

Ascorhynchus ramipes var. tsingtaoensis Lou, 1936a, p. 3, figs. 2-6, pl. 1, figs. 1-10; OHSHImA, 1936, p. 865 (listed only).

Ascorhynchus latus CaLman, 1923, p. 270, figs. 2-3.

Ascorhynchus latum $\mathrm{S}$ тоск, 1954, p. 128, fig. 63a-c.

A
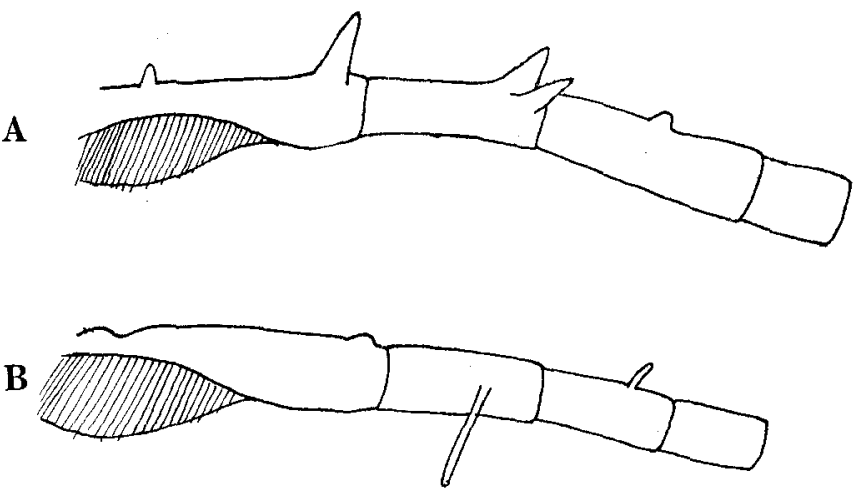

Fig. 4. Diagrammatic figures of crurigers and proximal joints of legs, showing the arrangment of tubercles and fingerlike process in Ascorhynchus auchenicum (A) and As. ramipes (B), lateral view from back.

Material: 2 males (Sp. No. Pycn. 8). Issiki, Hayama, 6 fathoms. 11-I-1930.

1 male and 1 ovigerous male (Sp. No. Pycn. 9). Issiki, Hayama, 6 fathoms. 19I-1930.

3 males and 3 ovigerous males (Sp. No. Pycn. 12). Off Kuruwa, 15-16 fathoms. 13-II-1950.

Remarks: All the specimens agree well with Lou's detailed descriptions of $A$ s. ramipes var. tsingtaoensis from North China and also of CALMAN's As. latus from the Gulf of Manaar, India and the Gulf of Siam, both of which are undoubtedly synonyms of As. ramipes (BöHM) originally described from Sagami Bay. Possibly both synonymies were deriven from BöHM's deficient description of the type specimen. 
This species seems to be nearly related to the preceding auchenicum. Yet it may be easily distinguished by the following characteristics:

The median tubercles on the trunk-dorsum are rather blunt, the distal tubercle on the crurigers are also knob-like. Of all the legs, coxa 1 is armed with a pair of finger-like processes extending horizontally near the distal end and coxa 2 with a shorter finger-like process dorsally projecting near the distal end. And also, the claw is absent in the first legs. A pair of small frontal tubercles are present on the head, but none on the dorsal surface of the stalk of the proboscis.

As all earlier records show, this species is apparently a shallow-water dweller and widely distributed in the Indo-West Pacific area.

Measurements of a male (No. 8) in $\mathrm{mm}$ :

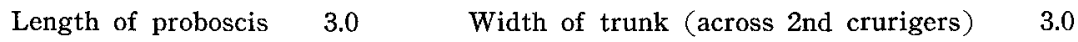

$\begin{array}{llll}\text { Length of trunk } & 5.5 & \text { Width of trunk (excluding crurigers) } & 0.7\end{array}$

$\begin{array}{lll}\text { Length of abdomen } & 2.5 & \text { Diameter of crurigers }\end{array}$

Length of crurigers 1.0

\section{Ascorhynchus glaberrimum SCHIMKEWITSCI}

Ascorhynchus glaberrimus ScHIMkewiTsch, 1929, p. 107, figs. 23-25; OHSHIMA, 1936, p. 865 (listed only).

Ascorhynchus glaberrimum UTINOMI, 1955, p. 26, fig. 15.

Material: 2 males (Sp. No. Pycn. 44). Between Kannonzuka-dasi and Aoyamadasi, Amadaiba, 76-78 m. 22-XII-1958.

Remarks: In the present two specimens, the dorsum of the trunk is destitute of median tubercles, 4 eyes near the tip of the ocular tubercle are non-pigmented and the terminal claw is small in the first legs. In the chelifores, the chelae are reduced to a minute rudiment, but the scape is short and robust.

Measurements of a male in $\mathrm{mm}$ :

$\begin{array}{llll}\text { Length of proboscis } & 3.0 & \text { Diameter of proboscis } & 1.5 \\ \text { Length of trunk } & 5.0 & \text { Length of crurigers } & 1.0 \\ \text { Length of abdomen } & 1.3 & \text { Length of chelifore } & 0.7\end{array}$

\section{Genus Lecythorhynchus Böнм, 1879}

Corniger BöHM, 1879a, p. 187 (name preoccupied).

Lecythorhynchus BöHM, 1879c, p. 140 ; НоEк, 1881, p. 27 ; COLE, 1904, p. 259, SCHIMKEwIтsCH, 1929, p. 48; Helfer \& Schlottke, 1935, p. 295 ; Hedgreth, 1949, 294 ; Sтоск, 1954, p. 139.

Emended diagnosis of the genus: Trunk slender, distinctly segmented with wellchitinized sutures. Legs slender, almost smooth, not much setigerous, with prominent chitinous septa or thickenings running dorso-medially in coxa 1 and laterally in the rest. Crurigers widely separated. Abdomen moderately robust. Proboscis cylindrical. Chelifore 1- or 2-jointed in adult; chela either reduced or present; if any, chelate 
or achelate. Palp long, 9-jointed, with S-like curved distal joints. Ovigers 10-jointed, with smooth or feebly denticulate spines. Propodus of all legs produced distally, claw strong, auxilliaries large.

Genotype: Lecythorhynchus hilgendorfi (BöнM).

Remarks: As discussed in detail by STOCK (1954, p. 141) under the genus Tanystylum, the genus Lecythorhynchus is closely related to Achelia, but differs from it in the one-jointed chelifores in adults, 9-jointed palps and well-segmented, elongate body, as far as the earlier known species are concerned. However, the finding of a new unique species ( $L$. hedgpethi as here named), having 2 -jointed palps in adults necessitates an emendation of the generic diagnosis.

The lobe-like extension in the 5th joint of the palps has been considered as a specific characteristics in L. marginatus CoLE. It is unusually developed in a new species $L$. hedgpethi and probably L. ovatus HILTON (if distinct). Probably its strong development concerns with the distortion of the flagellum-like distal joints, and therefore it may deserve one of the generic characteristics of Lecythorhynchus, as already recognized by Loman (1911, p. 9). Again, none of such special process for the genital opening as usually exists in Achelia is found in the 2nd coxae of legs. The structure of oviger spines and their arrangement resemble most closely those of Tanystylum. In these respects, Lecythorhynchus seems to be more related to the genus Tanystylum than to the genus Achelia within the Ammotheidae.

On the other hand, the conformation of the body and legs recalls the other families such as Nymphonidae, Phoxichilidiidae and Colossendeidae in the slenderness and the almost smoothness and also in the formation of distinct chitinous septa or thickenings along the mid-dorsal line in the first coxae and along the mid-lateral lines in the succeeding joints of all legs, though interruptedly in the middle of each joint.

The 3 species of the genus known at present are keyed as follows:

1 a) Chelifore 1-jointed, reduced in adults, though 2-jointed in larvae.

$1 \mathrm{~b})$ Chelifore 2-jointed, well developed in adults; body and legs not pigmented

L. hedgpethi n. sp.

2a) Body and legs banded by dark brownish patterns; 5th joint of palps more or less inflated ventrally.................................... L. hilgendorfi (BöHM) (=L. marginatus CoLE)

2b) Body and legs darkly pigmented; 5 th to 7 th joints bearing each a ventral lobe (if distinct) L. ovatus HILTON

\section{Lecythorhynchus hilgendorfi (BöнM) BöHM, syn. nov.}

(Figs. 5 \& 6)

Corniger hilgendorfi BöHM, 1879a, p. 187, pl. 2, figs. 3-3d.

Lecythorhynchus hilgendorfi BöHM, $1879 \mathrm{c}$, p. 140.

Lecythorhynchus hilgendorfi LOMAN, 1911, p. 8, pl. 2, figs. 28-29; OHSHIMA, 1927a, p. 610, figs. 1-3 ; OHshima, 1027 b, p. 380, pl. 7, figs. 1-6 ; Schimkewitsch, 1929 , p. 54 , figs. 10 11; OHshima, 1936, p. 867 (listed only) ; Lov, 1936b, p. 133, figs. 1-4, 5A \& pls. 11-13; 
OHSHIMA \& KISHIDA, 1947, p. 1009, fig. 2864; HedGPeTH, 1949, p. 296, fig. 44a-b; UTINOMT, 1951, p. 166 ; UTINOMI, 1954, p. 22.

Lecythorhynchus marginatus COLE, 1904, p. 260, pl. 11, figs. 1-2 \& pl. 15, figs. 1-8; SCHIMKEWITSCH, 1929, p. 50, figs. 7-9 ; SCHMITT, 1934, p. 69 ; HeLFER, 1938, p. 184 ; HILTON, 1939 a, p. 34 ; HrLton, 1939b, p. 73, pl. 2, fig. 10; HeDGPETH, 1941, p. 255 (keyed and figured) ; Hilton, 1943b, p. 4 ; Hedgreth, 1951, p. 111 ; HedGPeTH, 1954, p. 206, fig. 49j (keyed only); STOCK, 1954, p. 139, fig. 69a-c.
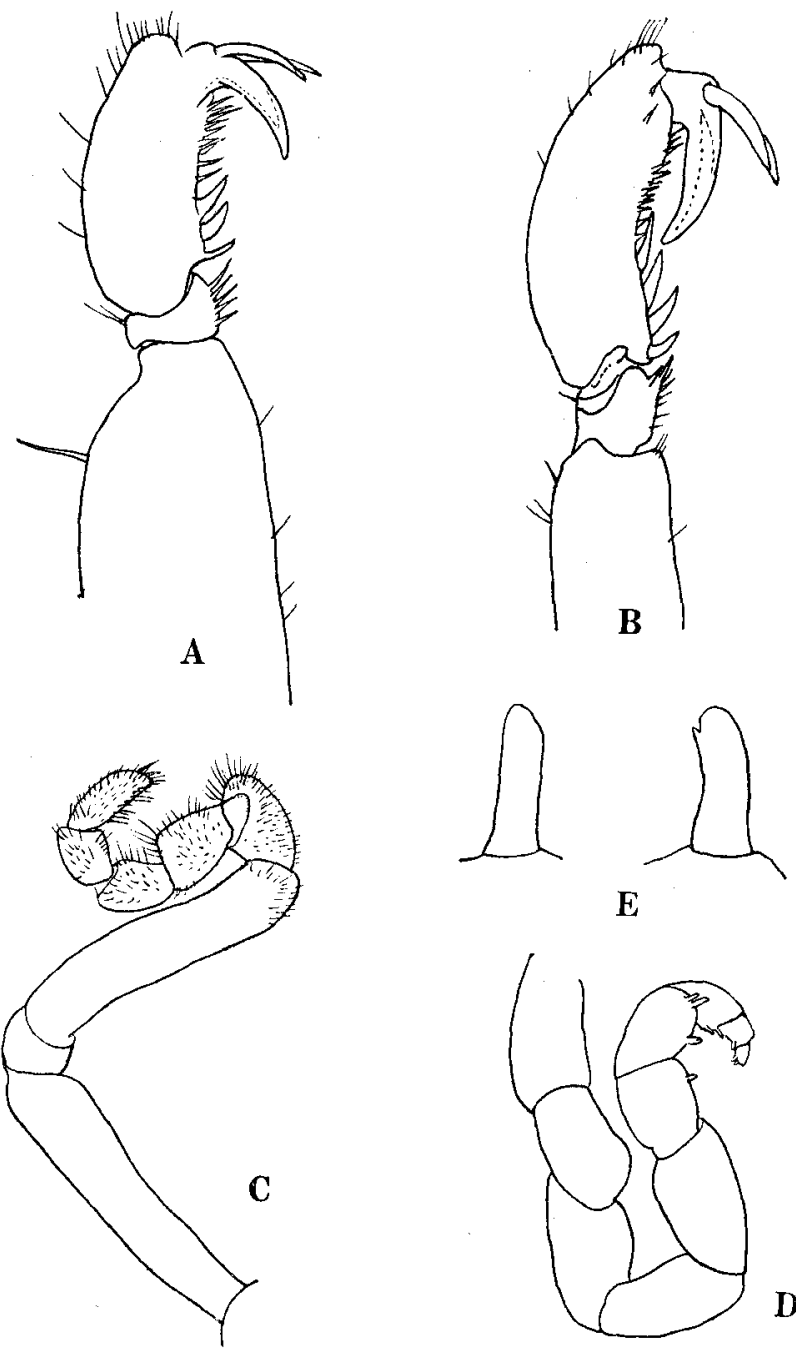

E

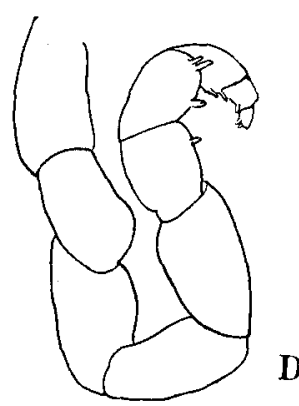

Fig. 5. Lecythorhynchus hilgendorfi (BöHM).

A, distal joints of a female (Sp. No. 11); B, the same of a male (Sp. No. 33); D, oviger of a female (Sp. No. 11); E, simple oviger spines of a female.

$(\mathrm{B}-\mathrm{C} \times 33, \mathrm{~A}, \mathrm{D} \times 55, \mathrm{E} \times 510)$ 
Material : 2 females (Sp. No. Pycn. 5c). $30 \mathrm{~m}$ south of Enosima. Depth unrecorded. 27-II-1938.

1 ovigerous male, 1 male and 4 females (Sp. No. Pycn. 20). Nazima, Hayama, shore. 20-VII-1952.

1 male (Sp. No. Pycn. 33). Mosaki, Kamegisyô, 7-8 fathoms. 22-VII-1957.

1 juvenile, lacking oviger (Sp. No. Pycn. 37). Mosaki, Kamegisyô, 7-8 fathoms. 22-VI-1957.

1 female (Sp. No. Pycn. 40). Kurosaki, shore. 29-VII-1958.
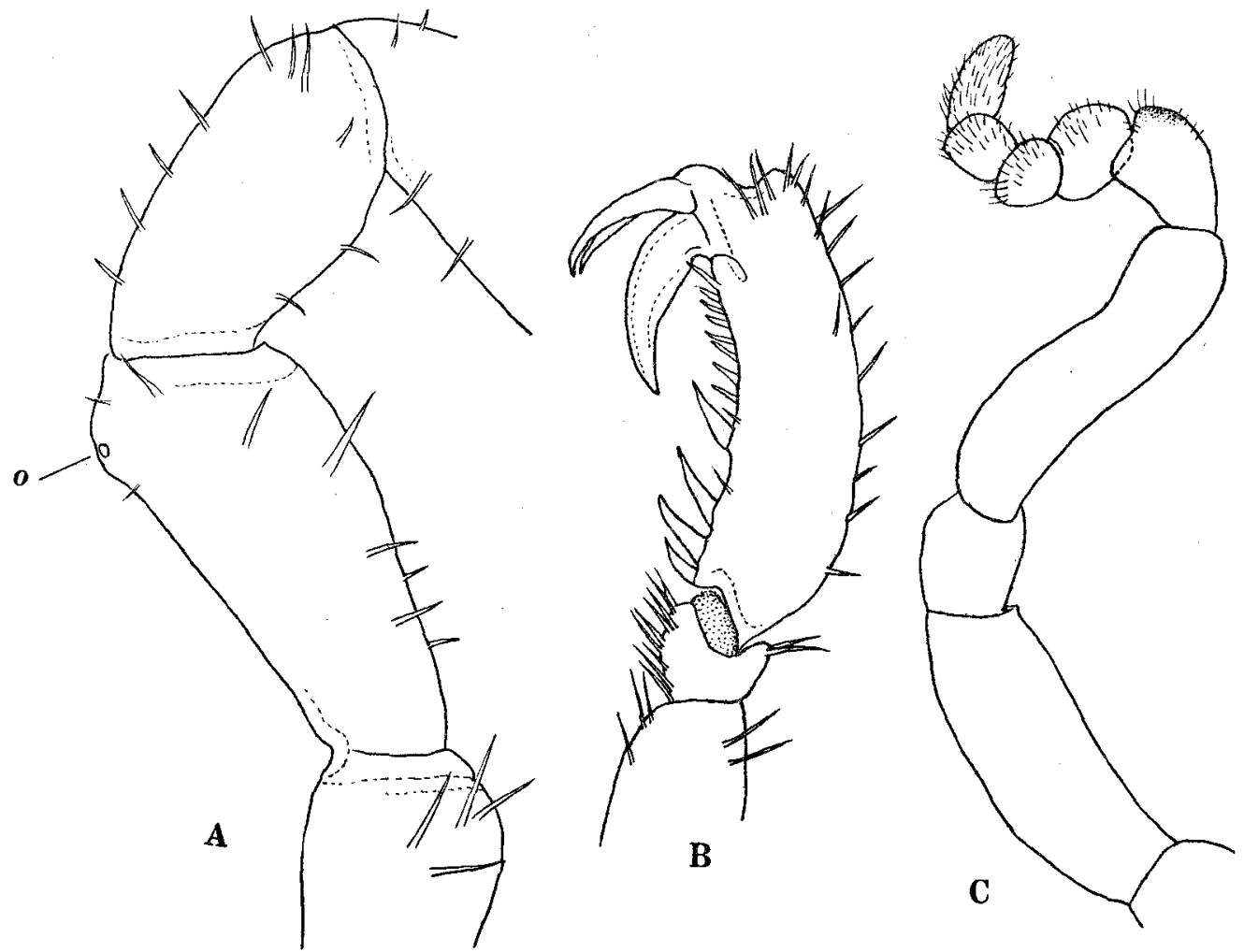

Fig. 6. Lecythorhynchus hilgendorfi (Böнм).

A, proximal joints of female leg, showing a genital opening $(o) ; \mathrm{B}$, distal joints of male leg; C, palp of a female (Sp. No. 11). (C $\times 55, A-B \times 67)$

Remarks: This species is fairly well represented on the Japanese coasts and thus the material of all stages is plentifully available for comparison.

This species was originally described by BӧнM (1879a,c) from Enosima in Sagami Bay, and seems to be prevalent all along the coasts of Japan, ranging from Hokkaido to China. Afterwards, some of the authors such as Schimkewitsch, LosinaLOSINSKY, HELFER and STOCK referred the specimens having the strongly inflated 5 th joint in the palps to L. marginatus which was first recorded by CoLE (1904) from 
the Californian coast (San Pedro Point and Dillon Beach), where it is very common according to American authors.

The principal differences between the two species, as enumerated by Sтоск (1954, p. 140), seem to be not absolutely distinctive, largely depending upon the relative length as well as size in every joint of the appendages, so that it may be subject to individual variation. Certainly wrong drawings, when mounted on a slide at different levels, are largely due to the strong curvature of palps, thus these may mislead one especially concerning the exact shape of the 5th and succeeding joints of palps, which form together a flagellum as in other crustacean antennae. The same may be said for the arrangement and number of compound spines on the ovigers. Two figures of palps retouched after original sketching by means of the camera lucida are given here for comparison (Figs. 5C and 6C). As figured herein, the 5th joint of the palps is more or less inflated ventrally, variable in individuals, though not so well pronounced as in the next hedgpethi $\mathrm{n}$. sp.

The genital opening is distinct on the ventral surface of the 2nd coxae of legs, situating on a slight protuberance near the distal end, but it is very minute (about $15 \mu$ in diameter) (cf. Fig. $6 \mathrm{~A}, o$ ).

As to the Hawaiian form L. ovatus, described by Hilton (1942b, 1943), I have no personal knowledge at present, but if HILTON's statement and figure are to be trusted, it may be a good species on account of the serrate appearance of the palps (according to HeDGPETH, however, that is illusory). Even if it is either distinct from L. hilgendorfi or not, at least CoLE's L. marginatus seems to be synonymous with L. hilgendorfi. Indeed, according to HedGPeTH (1951, p. $111 ; 1954$, p. 206), the Californian specimens also are marked in fresh material by conspicuous brownish purple bands on the legs (and trunk). To be sure, this littoral pycnogonid is widely distributed on both the coasts, east and west, in the northern Pacific, as in the case of Ammothella bi-unguiculata (DOHRN).

\section{Lecythorhynchus hedgpethi, spec. nov.}

(Figs. 7-9)

Material : 1 male (Sp. No. Pycn. 22-paratype). Warezima, 8 fathoms. 26-V-1952. 1 male (Sp. No. Pycn. 24-holotype). Off Hayama. Trawled. 1-II-1955.

1 male and 1 female, damaged (Sp. No. Pycn. 27-paratypes). Aoyama-dasi, Amadaiba, 80-90 m. 14-VI-1956.

1 male (Sp. No. Pycn. 32 paratype). Kannonzuka-dasi, Amadaiba, 80 m. 5-VI1957.

1 male (Sp. No. Pycn. 41-paratype). Between Kannonzuka-dasi and Maruyamadasi, $50 \mathrm{~m} .19-\mathrm{XII}-1958$.

Description of Holotype: Body much larger than that of L. hilgendorfi, but not pigmented whatever. Trunk rather stout, distinctly segmented; sutures well-chitinized; 
dorsum slightly ridged transversely in each segment in front of sutural lines. Cephalic segment slightly prolonged anteriorly, a little longer than wide in outline. Lateral processes a little longer than wide and separated by their own diameter. Ocular tubercle situated in the center of cephalic segment, erect, rather low, slightly pointed
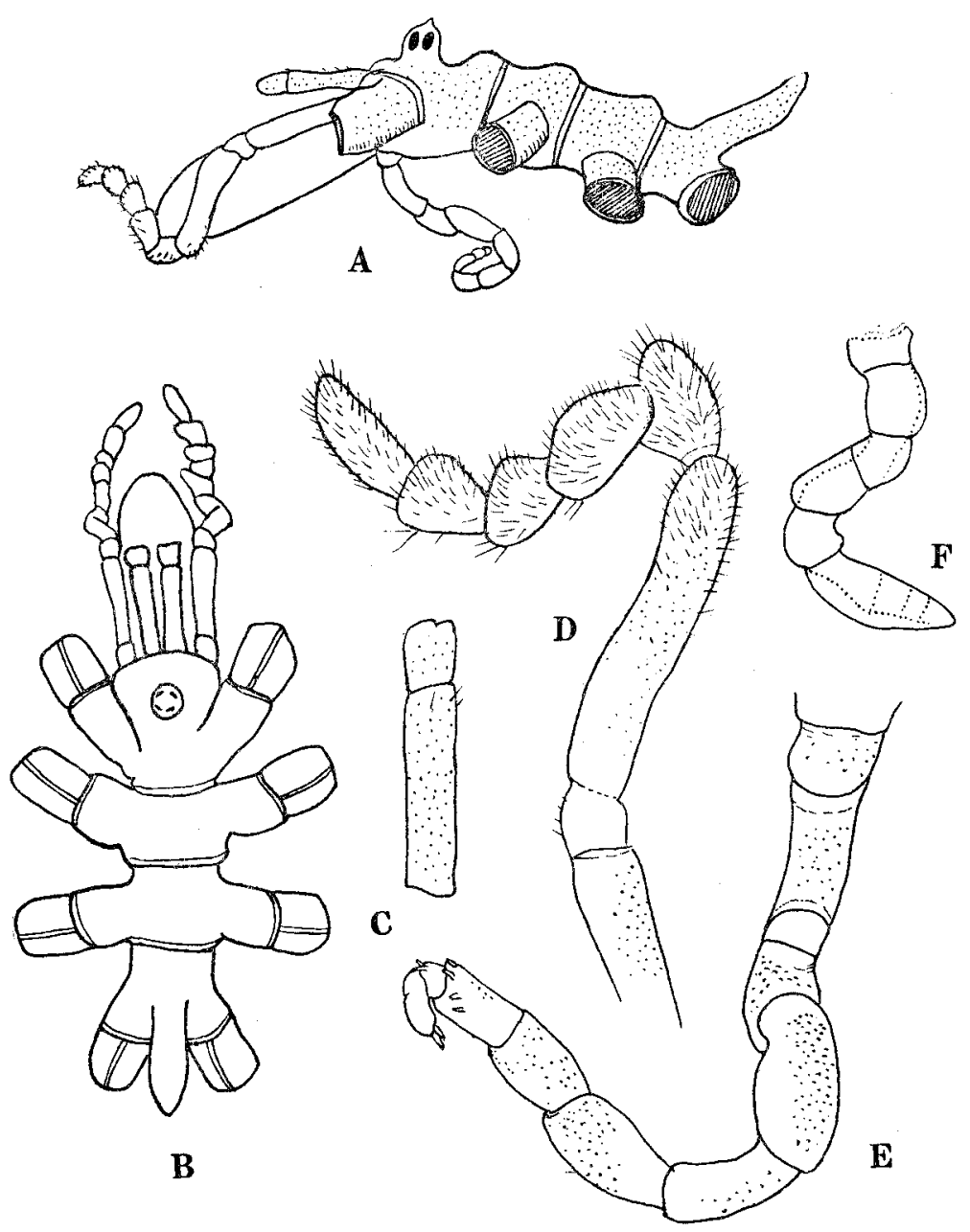

Fig. 7. Lecythorhynchus hedgpethi, n. sp.

A, male, paratype (Sp. No. 27), lateral view, legs omitted; B, the same, dorsal view; $C$, chelifore; $D$, palp; $E$, oviger of adult male (Sp. No. 27a); $\mathrm{F}$, oviger of immature female (Sp. No. $27 \mathrm{~b}$ ).

$(\mathrm{A}-\mathrm{B} \times 13, \mathrm{C}-\mathrm{F} \times 35)$

at tip, with 4 well-pigmented eyes. Abdomen comparatively long, elongate, projecting obliquely upwards. Surface minutely granular but not hairy.

Proboscis cylindrical, nearly as long as trunk, projecting obliquely downwards a little, somewhat tapering towards the base. 
Chelifore elongate, distinctly 2-jointed, as long as cephalic segment and slightly less than half the length of proboscis. Scape slender, elongate; chela short and achelate; surface granular, almost unhairy.

Palpus very long, 9-jointed, sharply curved upwards at the 5th joint which is conspicuously produced distally; strongly setose in distal joints. The 6th joint is inserted at middle of the upper surface of the 5 th joint. The terminal joint is elongate, somewhat flattened, a little longer and narrower than the penultimate joint.

Oviger 10-jointed, delicately granular and twisted in a complicated manner. Oviger spines, recalling those of the genus Tanystylum, are either simple or feebly denticulate and situated rather irregularly inside in the terminal 4 joints as in the

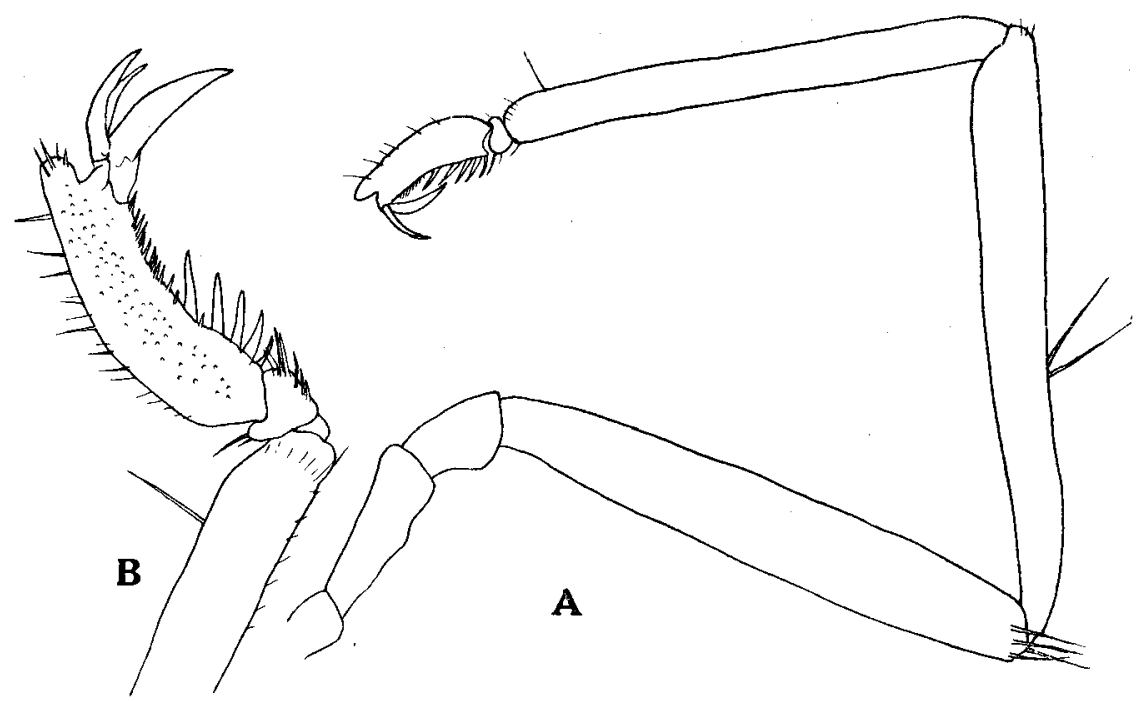

Fig. 8. Lecythorhynchus hedgpethi, n. sp.

A, fourth leg of a male, holotype (Sp. No. 24); B, distal joints of the same. $(\mathrm{A} \times 8, \mathrm{~B} \times 25)$

following manner-2:3:4:3:4. These number may vary when simple setae or spinules are counted together.

Legs considerably longer than in L. hilgendorfi and not pigmented whatever; they are somewhat over five times the length of the trunk, measuring about $20 \mathrm{~mm}$ in total length. All joints slender uniformly, smooth, though when examined in detail, feebly setose. Coxa 1 slightly longer than wide, coxa 2 about three times as long as wide with a slight swelling about midway on the dorsal surface and a slight swelling on the ventral surface distally, coxa 3 about half as long as coxa 2 but a little wider. Femur most plump of all joints and adorned with long setae dorso-distally. Tibia 1 rather plump but lesser than femur and scatteredly adorned with a few setae usually about midway. Tibia 2 longest of all joints, uniformly slender and adorned with a 
long seta near the distal end as in L. hilgendorfi. Tarsus shortest and armed with over 5 spines ventrally and with 1 or 2 spines dorsally. Propodus heavy, slightly curved, with a prominent distal process, armed ventrally with 5 basal spines and densely packed distal smaller spines and dorsally with many setae in a row, lateral surface strongly granular. Main claw strong, more than half the length of propodus; auxilliary claws rather strong, about $3 / 4$ as long as main claw.

Remarks: This new species may possibly be identical with an unnamed species obtained once at the 'Albatross' Station 3730 (southwest of Omaé-zaki, 34-37 fathoms) which HedGPETH (1949, p. 296, fig. 44 e-f) hegitatingly referred to the genus

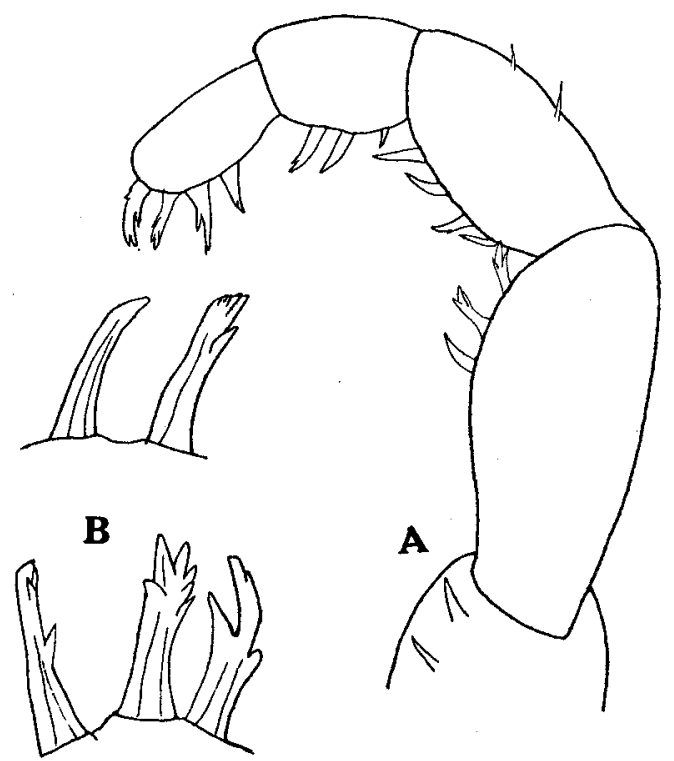

Fig. 9. Lecythorhynchus hedgpethi n. sp. A, distal joints of male oviger; B, simple or less denticulate oviger spines.

$(\mathrm{A} \times 75, \mathrm{~B} \times 300)$

Lecythorhynchus owing to the undeveloped appearance of the oviger and the uniquely 2 -jointed chelate chelifores. However, the general conformation of the body and all appendages suggests its closest affinity with the genus Lecythorhynchus, as discussed above. Indeed, in the case of $L$. hilgendorfi too, according to Lou's detailed study on the postembryonal development, the chelifores are distinctly 2 -jointed and chelate in larval stages, but later reduced to mere knobs in adults.

Therefore, a new name for this unique species is now given after Dr. HEDGPETH who first noticed it. The habitat of this new species is apparently deeper bottoms instead of intertidal. 
Measurements of a male (holotype) in $\mathrm{mm}$ :

Length of proboscis 2.5

Length of trunk $\quad 3.0$

Width of cephalic segment (at frontal edge) 1.0

Length of abdomen 1.5

Width of trunk across 2nd seg. (incl. crurigers) 1.5

Length of chelifore 1.0

Height of ocular tubercle

1.5
0.5

(scape

0.8 )

Fourth leg:

$\begin{array}{llll}\text { Coxa } 1 & 0.59 & \text { Tarsus } & 0.3 \\ \text { Coxa } 2 & 1.77 & \text { Propodus } & 1.77 \\ \text { Coxa } 3 & 1.08 & \text { Main claw } & 0.83 \\ \text { Femur } & 6.20 & \text { Auxilliary claws } & 0.47 \\ \text { Tibia } 1 & 6.50 & & \\ \text { Tibia } 2 & 7.97 & & \end{array}$

Family Pycnogonidae

Genus Pycnogonum BRUnNCH, 1764

18. Pycnogonum tenue KISHIDA

Pycnogonum littorale var. tenue SLATER, 1879, p. 283; ORTMAnN, 1890, p. 167; SCHIMkEwITSCH, 1929, p. 15.

Pycnogonum tenue Kishida, 1927, p. 989, fig. 1905; OHshima, 1936, p. 867 (listed only); OHshima \& KishidA. 1947, p. 1010, fig. 2865 ; HedGPETH, 1949, p. 303, figs. 48b, 50c-d ; STOCK, 1954, p. 162, fig. 80 ; Utinomi, 1955, p. 36, fig. 22.

Material: 1 male (Sp. No. Pycn. 25). Koronbo, west of Amadaiba, 250-300 m. 16-VII-1955.

Measurements of a male in $\mathrm{mm}$ :

Length of proboscis

2.5

Length of trunk

4.5

Length of abdomen

2.0

\section{Synopsis of Pycnogonids Hitherto Known from Sagami Bay and Its Surrounding Waters}

Nymphonidae

*Nymphon grossipes (O. FABRICIUS?) KR $\varnothing \mathrm{YER}$

UTinomi, 1955, p. 4 (Sôyô St. 269, off Simoda).

* Nymphon japonicum ORTMANN

OrTmann, 1890, p. 158 (the material from Sagami Bay is, according to STock,

a separate species $N$. ortmanni): Loman, 1911, p. 8 (various localities in Sagami Bay, $150-350 \mathrm{~m}$ ) ; OHshima, 1936, p. 862 (? Minami Amadaiba, $260 \mathrm{fms}$. as $N$.

* indicates the species contained in the collections of the His Majesty's Biological Laboratory and reported in this paper. 
macrum Wilson) ; Hedgreth, 1949, p. 249 (Albatross Sts. 3750, 3752, 3755, 3757, 41-140 fms.) ; STock, 1954, p. 18 (off Sunosaki, 20-80 fms.) ; Utinomi, 1955, p. 5 (Sôyô Sts. 239, 255, 258, 259, 270, 279, 286, 123-432 m).

Nymphon ortmanni HELFER

Helfer, 1938, p. 164 (Sagami Bay, as noted above); Stock, 1953a, p. 34 (Sagami

Bay); STock, 1954, p. 20 (off Misaki, Okinose, $80-120 \mathrm{fms}$.).

Nymphon micropedes HEDGPETH

Hedgreth, 1949, p. 254 (Albatross St. 5080, 505 fms.) ; OHshima \& Kishida, 1947, p. 1007 (Tokyo Bay \& Sagami Bay, as N. japonicum OrTmann).

Nymphon benthos HEDGPETH

HedGPETH, 1949, p. 256 (Albatross St. 5085, 622 fms.).

Nymphon nipponense HEDGPETH

HEDGpeth, 1949, p. 267 (Albatross St. 4980, Tôtômi-nada, 507 fms.).

Callipallenidae

*Propallene longiceps (BöHM)

Вӧнм, 1879 b, p. 59 (Enosima, as Pallene longiceps); Ortmann, 1890, p. 165

(Kadsiyama=Katuyama, as Pallene longiceps) ; Fukui, 1918, p. 97 (Kamakura, as Pallene longiceps); Ohshima, 1933a, p. 96, 1933c, p. 212 (Misaki, as Pallene longiceps) ; STOck, 1954, p. 31 (Misaki, $3 \mathrm{fms}$.).

Pallenopsis mollissima (HOEK)

HoEk, 1881, p. 87 (Challenger St. 237, off Bôsyû, 1875 fms., as Phoxichilidium mollissimum) ; HedGPETH, 1949, p. 277 (Albatross St. 5080, SW of Sagami Bay, 505 fms.).

* Pallenopsis virgata Loman

Hedgreth, 1949, p. 277 (Albatross St. 3730, SW of Omaé-zaki, 34-37 fms.).

Pallenopsis sibogae LOMAN

Utinomi, 1955, p. 19 (Sôyô St. 278, Suruga Bay, 79 m).

Pallenopsis spec.

Loman, 1911, p. 13 (Sagami Bay, as Pallenopsis n. sp. ? which is acc. to Schimkewitsch (1930, p. 237) probably P. hoekiana Schimkewitsch).

Phoxichilidiidae

Phoxichilidium ungellatum HEDGPETH

HedgPeth, 1949, p. 281 (Albatross Sts. 5079, 5080, SW of Omaé-zaki, 475-505 fms.) ; STock, 1954, p. 71 (Okinose, $100 \mathrm{fms}$ ).

Anoplodactylus gestiens (OrTMANN)

OrTMANN, 1890, p. 166 (Kadsiyama=Katuyama, 70-200 fms., as Phoxichilidium gestiens) ; Loman, 1911, p. 13 (Sagami Bay, 150-180 m) ; Hedgreth, 1949, p. 284 (Albatross Sts. 3703, 3715, 3739, Suruga Bay, 31-68 fms.); STock, 1954, p. 71 (off Misaki, Okinose, $80-120 \mathrm{fms}$.). 
Anoplodactylus mamillosus STock

SтосK, 1954, p. 72 (Sagami Bay, 300-400 fms.).

Anoplodactylus pycnosoma (HELFER)

Stock, 1953a, p. 41, 1954, p. 75 (Misaki, beneath low tide).

* Anoplodactylus versluysi LOMAN

Not ever recorded from Japan (incl. Sagami Bay).

Anoplodactylus spec.

Hedgpeth, 1949, p. 284 (Albatross Sts. 5075, 5078, Tôtômi-nada, 22-514 fms.). Anoplodactylus spec.

STock, 1954, p. 88 (Misaki, beneath low tide).

Ammotheidae

Achelia japonica UTINOMI

OrTmann, 1890, p. 164 (Kadsiyama = Katuyama, shallow water, as Achelia echinata var. japonica); Utinomi, 1954, p. 14 (renamed only).

* Achelia superba (LOMAN)

Loman, 1911, p. 11 (Sagami Bay, 80-180 m, as Ammothea superba) ; STock, 1954, p. 96 (Misaki, about 20 fms.) ; UTinomi, 1955, p. 23 (Sôyô St. 376, SW of Omaézaki, $64 \mathrm{~m}$ ).

*Achelia echinata HoDGE

Fukui, 1918, p. 97 (Hôzyô, ? as Achelia sp.); Sтock, 1956, p. 98 (off Misaki, $200 \mathrm{fms}$., as A. echinata ssp. nasuta).

Achelia bituberculata HEDGPETH

Hedgpeth, 1949, p. 287 (Misaki); STock, 1954, p. 94 (Misaki, coast).

Achelia spinosa (STIMPSON)

STOck, 1954, p. 96 (Sagami Sea, 400 fms.).

Achelia spec. (?) (larva)

Ohshima, 1933a, p. 94, 1933c, p. 61 \& p. 65 (Hôzyô, as Ammothea (?) sp. attached to a nudibranch Armina variolosa BERGH).

Ammothella profunda HedGPETH

Hedgreth, 1949, p. 289 (Albatross St. 5083, Tôtômi-nada, 624 fms.).

*Ammothella indica STOCK

Not ever recorded from Japan (including Sagami Bay).

*Nymphopsis muscosa LOMAN

Loman, 1911, p. 11 (off Misaki $50 \mathrm{~m}$, Zusi $130 \mathrm{~m}$ ).

*Cilunculus armatus (BӧHM)

BöHм, 1879 c, p. 141 (Enosima, as Lecythorhynchus armatus); ORTMANN, 1890, p. 163 (Kadsiyama=Katuyama, as Parazetes pubescens) ; Loman, 1911, p. 9 (off Enosima, Misaki \& Zusi, 80-131 m) ; HedGPETH, 1949, p. 274 (Albatross St. 3734, SW of Omaé-zaki, 36-48 fms.) ; UTinomi, 1955, p. 28 (Sôyô St. 236, off Sunosaki, Sagami Bay, $251 \mathrm{~m}$ ). 
Scipiolus spinosus UTINOMI

Utinomi, 1955, p. 31 (Sôyô St. 284, Senoumi, Suruga Bay, $71 \mathrm{~m}$ ).

Scipiolus validus STOCK

STock, 1957 a, p. 91 (Uraga Canal, 21 fms.).

*Ascorhynchus auchenicum (SLATER)

Ortmann, 1890, p. 162 (Tokyo Bay \& Sagami Bay, $100 \mathrm{fms}$., as Ascorhynchus bicornis) ; LoMAN, 1911, p. 6 (off Misaki 50-80 m, off Enosima $80 \mathrm{~m}$, as As. ramipes (part) ; Fukui, 1918, p. 97 (Hôzyô, as Ascorhynchus sp.) ; Schimkewitsch, 1929, p. 111 (Misaki, as As. minutus HoEK); Hedgpetr, 1949, p. 291 (Albatross St. 3707, off Osezaki, Suruga Bay, 60-70 fms.) ; STock, 1954, p. 124 (off Misaki, 3-300 fms.).

*Ascorhynchus ramipes (BöнM)

BöHm, 1879 b, p. 56 (Enosima, as Gnamptorhynchus ramipes); ORTManN, 1890, p. 161 (Sagami Bay, 50-100 fms.) ; Loman, 1911, p. 5 (Sagami Bay, 50-80 m (part); Hedgpeth, 1949, p. 292 (Tokyo Bay).

*Ascorhynchus japonicum IvES

IvEs, 1892, p. 219 (Loc. undeîned, shallow sea); Loman, 1911, p. 5 (Odawara, Hukuura) ; OHSHIMA, 1936, p. 865 (Amadaiba, 150-260 fms, 350-500 m ; off Kurosaki, 150 fms.) ; HedGPETH, 1949, p. 292 (Albatross Sts. 4980, 5079, 5082 \& 5084, Tôtômi-nada; Albatross St. 5094, Sagami Bay, 88-507 fms.) ; Sтоск, 1954, p. 126 (off Misaki, $80-120 \mathrm{fms}$.).

Ascorhynchus cryptopygium (ORTMANN)

Ortmann, 1890, p. 159 (Sagami Bay, 60-150 fms); Loman, 1911, p. 7 (Uraga Canal) ; Stock, 1954, p. 121 (Sagami Bay, 80-120 fms.); Utinomi, 1955, p. 24 (Sôyô St. 236, off Sunosaki, $251 \mathrm{~m}$ ).

Ascorhynchus glabroides ORTMANN

Loman, 1911, p. 7 (Sagami Bay).

*Ascorhynchus glaberrimum ScHIMKEWITSCH

Not ever recorded from Sagami Bay.

*Lecythorhynchus hilgendorfi (Böнм)

Böнm, 1879 a, p. 187 (Enosima, 3-4 fms., as Corniger hilgendorfi) ; Böнm, 1879 c, p. 140 (Enosima, renamed as above); Loman, 1911, p. 8 (Enosima, redescribed Böhm's type); Ohshima, 1933 a, p. 95 (Tateyama Bay) ; Hedgreth, 1949, p. 296 (near Chochi $=$ Chôshi or Tyôsi, northeast cape of Bôsô Peninsula); STock, 1954, p. 139 (Misaki, shore, as L. marginatus).

*Lecythorhynchus hedgpethi UTiNOMI (n. sp.)

Hedgreth, 1949, p. 296 (Albatross St. 3730, SW of Omaé-zaki, Tôtômi-nada, 34-37 fms., as ? L. spec.).

Tanystylum scrutator STOCK

STOCK, 1954, p. 142 (Misaki, shore). 


\section{Austrodecidae}

Austrodecus tubiferum STOCK

Sтоск, 1954, p. 153 (Okinose, 100 fms., as A. gordonae (part)); STock, 1957 b, p. 75 (Okinose, renamed as above).

\section{Colossendeidae}

Colossendeis japonica HOEK

HOEK, 1898, p. 295 (Challenger St. 237, off Bôsô Peninsula, 1875 fms.).

Colossendeis colossea WILsON

Loman, 1911, p. 4 (Sagami Bay, as C. gigas Hoek); Hedgpeth, 1949, p. 299 (Albatross St. 5082, Tôtômi-nada, $662 \mathrm{fms}$.).

Colossendeis macerrima WILSON

Loman, 1911, p. 4 (Okinose Bank, $1400 \mathrm{~m}$, as C. leptorhynchus HoEk); Hedgreth, 1949, p. 299 (Albatross St. 5083, Tôtômi-nada, 624 fms.).

Colossendeis dofleini LOMAN

Loman, 1911, p. 4 (near Misaki); Hedgpeth, 1949, p. 300 (Albatross St. 5079, Tôtômi-nada, 475-505 frns.).

Colossendeis chitinosa HrLTON

Hedgreth, 1949, p. 301 (Albatross St. 3703, Senoumi, Suruga Bay, 31 fms. \& Sagami Bay).

\section{Pycnogonidae}

\section{*Pycynogonum tenue KISHIDA}

Ortmann, 1890, p. 167 (Sagami Bay, 100 fms., as P. litorale var. tenue Slater); KISHIDA, 1927, p. 989 (Locality not given); HEDGPETH, 1949, p. 303 (Albatross Sts. 3707, 3708, 3716; Osezaki, Suruga Bay, 60-125 m).

Pycnogonum ungellatum LOMAN

Loman, 1911, p. 7 (Sagami Bay).

\section{REFERENCES}

(Especially concerned with the Japanese fauna.)

BöHM, R. 1879a. Ueber die Pycnogoniden des Königl. zoologischen Museums zu Berlin, insbesondere iiber die von S. M. Gazelle mitgebrachten Arten. Monatsber. Berlin Akad. Wiss., 1879, pp. 170-197, 2 pls.

1879b. Ueber $z$ wei neue von Dr. Hilgendorf in Japan gesammelte Pycnogoniden. Sitzb. Ges. Naturf. Freunde Berlin, 1879, no. 1, pp. 53-60.

1879c. Ueber Pycnogoniden. Ibid., 1879, no. 9, pp. 140-142.

Calman, W. T. 1922. The holotype of Parazetes auchenicus, Slater (Pycnogonida). Ann. Mag. Nat. Hist., ser. 9, vol. 9, pp. 199-203, 4 figs. 1923. Pycnogonida of the Indian Museum. Rec. Indian Mus., vol. 25, pt. 3, pp. 265-299, figs. $1-17$. 
Calman, W. T. 1938. Pycnogonida. The John Murray Exp. 1933-34, Sci. Rep., vol. 5, no. 6, pp. $147-166$, figs. $1-10$.

Cole, Leon J. 1904. Pycnogonida of the west coast of North America. Harriman Alaska Exp., vol. 10, pp. 249-298, pls. 11-26.

FukuI, Tamao 1919. Structure of Pycnogonida and their species hitherto known from Japan. Rigakukai, vol. 16, no. 2, pp. 95-99. (In Japanese)

Hedgpeth, Joel W. 1941. A key to the Pycnogonida of the Pacific coast of North America. Trans. San Diego Soc. Nat. Hist., vol. 9, no. 26, pp. 253-264, pls. 9-11.

1948. The Pycnogonida of the western North Atlantic and the Caribbean. Proc. U. S.

Natl. Mus., vol. 97, no. 3216, pp. 157-342, figs. 4-53, charts 1-3.

1949. Report on the Pycnogonida collected by the Albatross in Japanese waters in 1900 and 1906. Ibid., vol. 98, no. 3231, pp. 233-321, figs. 18-51.

1951. Pycnogonids from Dillon Beach and vicinity, California, with descriptions of two

new species. Wasmann Journ. Biol., vol. 9, no. 1, pp. 105-117, pls. 1-3.

1954. Class Pycnogonida. In: SMITH, Ralph I. et al. Intertidal Invertebrates of the

Central California coast, pp. 201-210. Univ. Calif. Univ. Press, Berkeley and Los Angeles.

Helfer, Hermann 1938. Einige neue Pantopoden aus der Sammlung des Zoologischen Museums in Berlin. Sitzber. Ges. Naturf. Freunde Berlin, 1937, pp. 162-185, figs. 1-11.

\& Schlottke, Egon 1935. Pantopoda. Bronns Klassen u. Ordn. Tierreichs, Bd. 5, Abt. 4, Buch 2. Akad. Verlagsges., Leipzig. 314 pp., 223 figs.

Hilton, William A. 1939a. A preliminary list of Pycnognids (sic) from the shores of California. Journ. Entom. \& Zool. (Pomona Coll.), vol. 31, no. 2, pp. 27-35.

1939b. A collection of pycnognids (sic) from Santa Cruz Island. Ibid., vol. 31, no. 4, pp. $72-74$, pls. $1-2$.

1942a. Pycnogonids from Allan Hancock Expeditions. Allan Hancock Pacific Exped., vol. 5, no. 9, pp. 277-339, pls. 35-48.

1942b. Pycnogonids from Hawaii. Occ. Pap. Bernice P. Bishop Mus., vol. 17, no. 3 pp. 43-55, figs. $1-10$.

1943. Pycnogonids from the Pacific. Family Colossendeidae. Journ. Entom. \& Zool. (Pomona Coll.), vol. 35, no. 1, pp. 2-4.

Hodge, G. 1864. List of the British Pycnogonidea, with descriptions of several new species. Ann. Mag. Nat. Hist., ser. 3, vol. 13, pp. 113-117, pls. 12-13.

HoEK, P. P. C. 1881. Report on the Pycnogonida dredged by H. M. S. Challenger during the years 1873-1876. Challenger Reports, Zool., vol. 3, no. 10, pp. 1-167, pls. 1-21.

1898. On four pycnogonids, dredged during the cruise of the Challenger. Tijdschr.

Ned. Dierk. Ver., rer. 2, vol. 5, pp. 290-300, pls. 2-3.

IVES, J. E. 1892. Echinoderms and arthropods from Japan. Proc. Acad. Nat. Sci. Philadelphia, vol. 43 (1891), pp. $210-223$, pls. $7-12$.

KishidA, K. 1927. Pantopoda. In : Figuraro de Japanaj Bestoj, pp. 989-990, figs. 1905-1908. Hokuryûkan, Tokyo. (In Japanese)

Loman, J. C. C. 1908. Die Pantopoden der Siboga-Expedition. Siboga-Expeditie, Mon. 40, pp. 1 88, pls. $1-15$.

1911. Japanische Podosomata. Abh. math.-phys. Kl. K. Bayer. Akad. Wiss. II. Suppl..

Bd. 4 Abhandl., pp. 1-18, pls. 1-2.

Losina-Losinsky, L. K. 1933. Die Pantopoden der östlichen Meere der USSR. Leningrad Inst. Issledovanija Morei SSSR, vol. 17, pp. 43-80, figs. 1-13.

Lou, Ting-Heng 1936a. Sur deux nouvelles variétés des pycnogonides recueillies à Tsing-Tao, dans la baie de Kiao-Chow, Chine. Contr. Inst. Zool. Nat. Acad. Peiping, vol. 3, no. 1, pp. 1-34, 9 text-figs. pls. $1-4$.

1936b. Note sur Lecythorhynchus hilgendorfi Böhm (Pycnogonida). Ibid., vol. 3, no. 5, pp. 133-163, 6 text-figs., pls. 11-13. 
Marcus, Ernesto 1940. Os Pantopoda brasileiros e os demais sul-americannos. Bol. Fac. Fil., Ciênc. Letr. Univ. S. Paulo, vol. 19, Zoologia no. 4, pp. 3-179, pls. 1-17.

OHshima, Hiroshi 1927a. Notes on some pycnogons living semiparasitic on holothurians. Proc. Imp. Acad. Tokyo, vol. 3, no. 9, pp. 610-613, figs. 1-4.

1927b. Piknogonoj alkroĉighantaj al Holoturioj. Bult. Sci. Fac. Sci. Fac. Terk. Kjuŝu Imp. Univ., vol. 2, no. 5, pp. 380-388, pl. 7. (In Japanese with Esperanto rés.)

1933a. 4 notes on sea-spiders. Zool. Mag. Tokyo, vol. 45, nos. 532/533, pp. 94-96.

(In Japanese)

1933b. Young pycnogonids found parasitic on nudibranchs. Annot. Zool. Japon., vol. 14, no. 1 , pp. 61-66, 5 figs.

1933c. Pycnogonids taken with a tow-net. Ibid., vol. 14, no. 2, pp. 211-220, 14 figs.

1936. A list of Pycnogonida recorded from Japanese (sic) and adjacent waters. Zool.

Mag. Tokyo, vol. 48, nos. 8-10, pp. 861-869. (In Japanese, with English rés.)

\& KISHIDA, K. 1947. Pantopoda. In : Illustrated Encyclopedia of the fauna of Japan.

Revised edition, pp. 1005-1010, figs. 2855-2866. Hokuryukan. Tokyo. (In Japanese.)

Ortmann, A. 1890. Bericht über die von Herrn Döderlein in Japan gesammelten Pycnogoniden.

Zool. Jahrb., Abt. Syst., vol. 5, pt. 1, pp. 157-168, pl. 24.

Schimkewitsch, W. 1929. Pantopoda. Livr. 1. Faune de 1'URSS et des pays limitrophes. Leningrad. I-CXV, 1-224, pls. 1-4, 57 text-figs. 1930. Pantopoda. Livr. 2. Ibid., pp. $225-555$, pls. 5-10, text-figs. 58-166.

Slater, H. H. 1879. On a new genus of pycnogon and a variety of Pycnogonum littorale from Japan. Ann. Mag. Nat. Hist., ser. 5, vol. 3, no. 16, pp. 281-293.

STOck, J. H. 1953a. Re-description of some of Helfer's pycnogonid type-specimens. Beaufortia, vol. 4 , no. 35 , pp. $33-45$, 6 figs.

1953b. Contribution to the knowledge of the pycnogonid fauna of the East Indian

Archipelago. Temminckia, vol. 9, pp. 276-313, 18 figs.

1954. Pycnogonida from Indo.West-Pacific, Australian, and New Zealand waters. Vidensk.

Meddel. Dansk Naturh. Foren., vol. 116, pp. 1-168, figs. 1-81.

1955. Pycnogonida from the West Indies, Central America, and the Pacific coast of

North America. Ibid., vol. 117, pp. 209-266, figs. 1-26.

1956. Tropical and subtropical Pycnogonida, chiefly from South Africa. Ibid., vol. 118,

pp. 71-113, figs. 1-16.

1957a. Pantopoden aus dem Zoologischen Museum Hamburg. 2 Teil. IV-VI. Mitt.

Hamburg. Zool. Mus. Inst., vol. 55, pp. 81-106, figs. 1-20.

1957b. The pycnogonid family Austrodecidae. Beaufortia, vol. 6, no. 68, pp. 1-81, figs. 1-43.

1958. Contributions to the knowledge of the Red Sea. No. 5. The Pycnogonida of the Erythrean and of the Mediterranean coasts of Israel. Bull. Sea Fish. Res. Sta. Haifa, No. 16, pp. 1-3.

Utinomi, Huzio 1951. On some pycnogonids from the sea around Kii Peninsula. Publ. Seto Mar. Biol. Lab., vol. 1, no. 4, pp. 159-168, figs. 1-2.

1954. The fauna of Akkeshi Bay, XIX. Littoral Pycnogonida. Publ. Akkeshi Mar. Biol.

Stat., no. 3, pp. 1-28, text-figs. 1-11, pl. 1.

1955. Report on the Pycnogonida collected by the Sôyô-maru Expedition made on the continental shelf bordering Japan during the years 1926-1930. Publ. Seto Mar. Biol. Lab., vol. 5 , no. 1 , pp. $1-42$, text-figs. $1-24$. 